\title{
Pelatihan Pembuatan Desain Kemasan Produk Pada UKM Sari Ne Lemon
}

\author{
Ni Putu Desy Damayanthi ${ }^{1}$, IGKG Puritan Wijaya ADH ${ }^{2}$, Ni Nyoman Utami Januhari ${ }^{3}$, I Made Surya Adi Putra ${ }^{4}$, \\ I Gusti Agung Indra Muliawan ${ }^{5}$, I Putu Kusa Satrialandipa Putra ${ }^{6}$, Komang Nova Triana Putra, \\ I Made Bhaskara Gautama ${ }^{8}$, I Nyoman Rudy Hendrawan ${ }^{9}$, I Made Arya Budhi Saputra ${ }^{10^{*}}$ \\ 1,2,3,5,6,7,8,9,10 Fakultas Informatika dan Komputer, Institut Teknologi dan Bisnis STIKOM Bali \\ ${ }^{4}$ Sekolah Menengah Kejuruan 1 Petang \\ ${ }^{1}$ desy.damayanthi91@gmail.com, ${ }^{2}$ puri@stikom-bali.ac.id, ${ }^{3}$ ami@ stikom-bali.ac.id, ${ }^{4}$ surya.adi.p.41@ gmail.com, \\ ${ }^{5}$ ngurahindra@gmail.com, ${ }^{6}$ satrialandipa@gmail.com, ${ }^{7}$ komangnnova@gmail.com, ${ }^{8}$ bhaskara@ stikom-bali.ac.id, \\ ${ }^{9}$ rudyhendrawan@ stikom-bali.ac.id, ${ }^{10}$ aryabudhi@ stikom-bali.ac.id*
}

\begin{abstract}
Sari Ne Lemon in East Denpasar is an UKM that is active in lemon cultivation. The lemon plantation owned by Sari Ne Lemon is located in Pelaga Village, Petang District, Badung Regency. Although the lemon plantation is currently still in the village of Petang, the production and sales center is located in East Denpasar. Initially the results of the cultivation of lemon plantations were only in the form of lemons that had not undergone further processing. Currently, Sari Ne Lemon has developed lemon juice into packaged lemon juice. In its effort to develop lemon juice products, Sari Ne Lemon encountered difficulties in terms of packaging and marketing. The packaging owned by Sari Ne Lemon is still very simple, namely lemon juice is packaged and sold in plastic bottles. Therefore, the resulting product has not been able to compete in the industrial market. This service activity aims to find and implement solutions to the problems experienced by partners. Packaging that is only in the form of plastic bottles without labels will be changed into 2 types of packaging, namely labeled plastic bottle packaging and labeled plastic press glass packaging. With the activities of making branding and training on packaging of processed lemon juice products, it will produce products that have higher competitiveness and selling value. UKM Sari Ne Lemon has been helped by the successful development of their new product packaging through packaging design and implementation in $14 \mathrm{oz}$ glass cups and small plastic bottles.
\end{abstract}

Keywords: UKM, lemon, design, packaging

\begin{abstract}
Abstrak
Sari Ne Lemon yang ada di Denpasar Timur adalah UKM yang aktif dalam budidaya jeruk lemon. Perkebunan jeruk lemon yang dimiliki oleh Sari Ne Lemon yakni berada di desa Pelaga, kecamatan Petang. Walaupun perkebunan jeruk lemon saat ini masih berada di desa Petang, namun pusat produksi dan penjualan ini berlokasi di Denpasar Timur. Awalnya hasil dari budidaya perkebunan lemon hanya berupa jeruk lemon yang belum mengalami proses pengolahan lebih lanjut. Saat ini Sari Ne Lemon sudah mengembangkan jeruk lemon menjadi sari lemon dalam kemasan. Dalam usahanya mengembangkan produk sari lemon, Sari Ne Lemon mengalami kesulitan dalam hal pengemasan dan pemasaran. Pengemasan yang dimiliki oleh Sari Ne Lemon masih sangat sederhana yaitu perasan lemon dikemas dan dijual dalam botol plastik. Oleh sebab itu, produk yang dihasilkan belum bisa bersaing di dalam pasar industri. Kegiatan pengabdian ini bertujuan untuk mencari dan menerapkan solusi atas permasalahan yang dialami oleh mitra. Kemasan yang hanya berupa botol plastik tanpa label akan diubah menjadi 2 tipe kemasan yakni kemasan botol plastik berlabel dan kemasan gelas plastik press berlabel. Dengan kegiatan pembuatan branding dan pelatihan pengemasan produk olahan sari lemon akan menghasilkan produk yang memiliki daya saing dan nilai jual yang lebih tinggi. UKM Sari Ne lemon telah terbantu dengan berhasilnya mengembangkan kemasan produk baru mereka melalui desain kemasan dan implementasinya pada kemasan gelas cup ukuran $400 \mathrm{ml}$ dan botol plastik kecil.
\end{abstract}

Kata Kunci: ukm, lemon,desain,kemasan 


\section{PENDAHULUAN}

Pertumbuhan sektor pertanian yang sudah maju perlu menjadi perhatian pertumbuhan ekonomi di Bali (Kesumadewi et al., 2020). Karena selain pariwisata, sektor pertanian (Yuendini et al., 2019), menjadi sektor unggulan yang harus diperhatikan oleh pemerintah baik daerah maupun pusat. Tingginya alih fungsi lahan dan krisinya generasi muda yang bergerak dalam, bidang pertanian mengancam sektor pertanian dan ketersediaan pasokan kebutuhan bahan makanan yang dihadapkan pada peningkatan permintaan yang didorong oleh perkembangan pariwisata. Selain alih fungsi lahan resiko yang berpotensi buruk adalah anomali iklim sehingga menghambat kinerja pertanian.

Sari Ne Lemon yang ada di Denpasar Timur adalah UKM yang aktif dalam budidaya jeruk lemon. Perkebunan jeruk lemon yang dimiliki oleh Sari Ne Lemon yakni berada di desa Pelaga, Kecamatan Petang, Kabupaten Badung. Perkebunan jeruk lemon saat ini berada di desa Petang, Kabupaten Badung, namun kantor kelompok pemuda tani ini berlokasi di Denpasar Timur. Para petani menjual hasil dari budidaya perkebunan lemon hanya berupa buah yang belum mengalami proses pengolahan lebih lanjut. Para petani muda ini kemudian melakukan pengolahan jeruk lemon menjadi sari lemon dalam kemasan. Dalam usahanya mengembangkan produk sari lemon, sari lemon merupakan air perasan lemon yang diolah dan memiliki vitamin $\mathrm{C}$ yang tinggi (Trisnawati, 2018).

Walau sudah memiliki Logo dan Merk UKM Sari Ne Lemon mengalami kesulitan dalam hal pengemasan produk. Pengemasan yang dimiliki oleh Sari Ne Lemon masih sangat sederhana. Kemasan yang digunakan yakni menggunakan kemasan botol plastik tanpa label serta Logo belum diterapkan pada kemasaan. Padahal, dengan kemasan yang baik dan memiliki ciri khas, dapat mempermudah proses pemasaran (Wijaya et al., 2020). Pengemasan produk yang masih sangat sederhana ini belum dapat menarik minat para konsumen dalam membeli produk olahan jeruk lemon tersebut .

Oleh sebab itu, produk yang dihasilkan belum bisa bersaing di dalam pasar industri. Terlihat pada gambar 1, hasil perasan sari lemon sudah dikemas dalam bentuk botol namun tanpa label dan terlihat kurang menarik (Apriyanti, 2018). Padahal sebuah kemasan sangat menentukan jumlah produk yang dapat terjual (Purnaningrum, 2018).

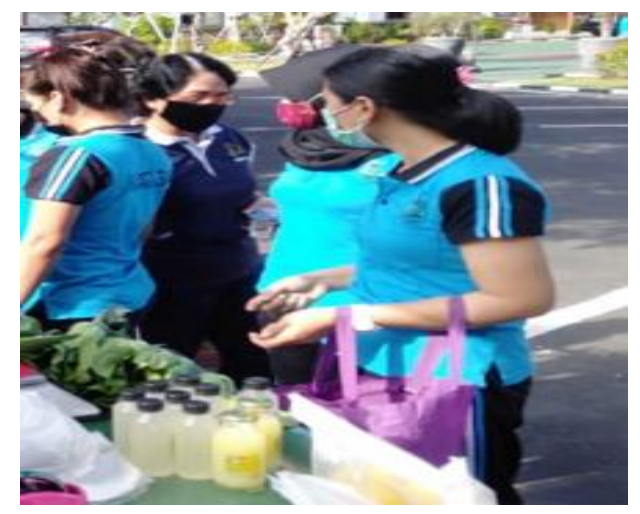

Gambar 1. Perasan Lemon Dijual Pada Pasar Umum

Kegiatan pengabdian ini bertujuan untuk mencari dan menerapkan solusi atas permasalahan yang dialami oleh mitra. Kemasan yang hanya berupa botol plastik tanpa label akan diubah menjadi 2 tipe kemasan yang lebih baik yakni tetap menggunakan kemasan botol plastik denga menambahkan label dan kemasan gelas plastik press berlabel. Penambahan label pada masingmasing kemasan bertujuan untuk memberikan identitas produk yang dimiliki oleh Sari Ne Lemon.

Berdasarkan analisis situasi, permasalahan yang dihadapi oleh mitra adalah Sari Ne Lemon dalam hal pengemasan produk olahan sari lemon masih sangat sederhana dan belum memiliki daya tarik bagi konsumen.

Peran dari mitra pada kegiatan ini adalah menyiapkan lokasi dan peserta pelatihan. Kegiatan pelatihan dilaksanakan di rumah mitra dengan peserta sejumlah 5 orang.

Solusi yang ditawarkan sesuai dengan permasalahan yang dialami oleh mitra adalah dengan memperbaharui dengan memberikan bantuan desain kemasan produk sari lemon dengan menggunakan kemasan botol plastik dan gelas plastik press. Kemasan botol plastik dan gelas plastik press ini ditambahkan dengan label sebagai indentitas produk. Alasan pemilihan solusi tersebut antara lain untuk menambah daya tarik konsumen dan memberikan identitas pada produk. Hal ini membantu 
produk dari mitra agar lebih dikenal oleh masyarakat secara umum.

\section{METODE}

Mitra pengabdian kepada masyarakat, yaitu Sari Ne Lemon yang memiliki kantor berlokasi di Jalan Tegal Sari No. 19, Kesiman - Denpasar Timur. Mitra berjarak kurang lebih 5,2 Km yang dapat ditempuh dalam waktu kurang lebih 20 menit dari kampus Institut Teknologi dan Bisnis STIKOM Bali melalui jalur terdekat. Lokasi bisa dilihat pada Gambar 2.

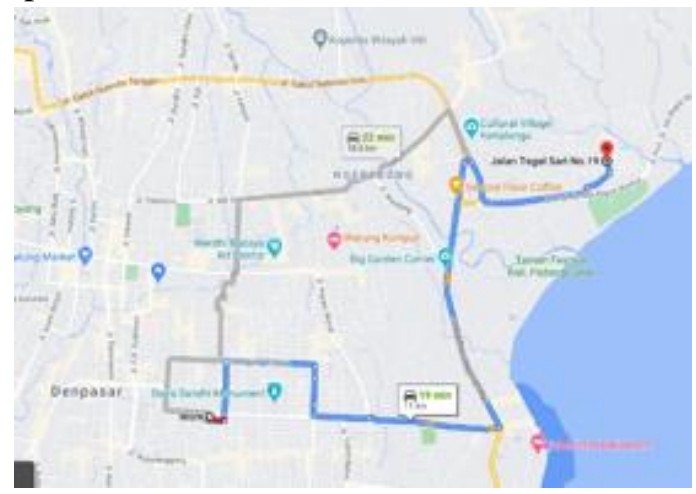

Gambar 2. Peta Lokasi

Berikut adalah gambaran umum kegiatan yang telah dilakukan pada industri rumah tangga/ UMKM Sari Ne Lemon pada gambar 3 .

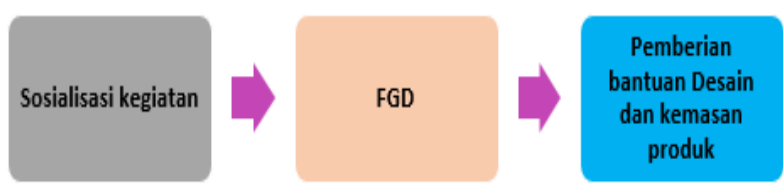

Gambar 3. Gambaran Umum Kegiatan

\section{Sosialisasi kegiatan secara online}

Kegiatan ini dilakukan untuk memberikan pemahaman kepada mitra tentang kegiatan pengabdian masyarakat. Ketua, anggota, dan mitra pengabdian melakukan pertemuan online untuk membahas seputar masalah pengabdian kepada masyarakat, hak, kewajiban, dan melakukan konfirmasi kesediaan mitra.

\section{Focus Group Discussion}

Focus Group Discussion (FGD) dilakukan untuk memperoleh data mitra, permasalahan, beserta membicarakan solusi terbaik yang dapat diberikan kepada mitra pengabdian. Kegiatan ini dilakukan bersama mitra sejumlah 10 orang dan tim pengabdian sebanyak 5 orang.

3. Pemberian bantuan Desain kemasan produk dan label dan pelatihan mengemas produk

Bantuan yang diberikan berupa Desain kemasan dan 200 buah kemasan botol plastik beserta label dan 200 gelas plastik press berlabel. Kemasan ini digunakan untuk mem-branding dan mensukseskan kegiatan pemasaran produk sari lemon yang dimiliki oleh Sari $\mathrm{Ne}$ Lemon.

\section{HASIL DAN PEMBAHASAN}

Teknik evaluasi yang digunakan pada kegiatan ini adalah pemberian kuisioner kepuasan peserta dari mitra yang berjumlah 10 orang.

Sebelum kegiatan FGD dilakukan tahapan yang telah dicapai adalah sebagai berikut :

\section{Diskusi Produk Baru Sari Ne Lemon}

UKM Sari ne Lemon menyampaikan bahwa produk baru mereka perlu dibuatkan Desain Kemasan Serta penempatan logo mereka pada desain kemasan tersebut. Produk yang mereka jelaskan didapat adalah perpaduan Olahan Sari Lemon dengan campuran Gula Alami tanpa pengawet dengan proses penabmahan soda yang disajikan pada gelas cup Ukuran $400 \mathrm{ml}$. Berdasarkan deskripsi tersebut kami mengusulkan dan memberi nama Sparkling Lemon.

\section{Desain Logo dan Tagline Produk baru Sparkling} Lemon - Sari ne Lemon

Desain logo dibuat berdasarkan kebutuhan dan deskripsi yang telah didapatkan sebelumnya maka berikut adalah hasil desain logo kemasan dan tagline "Good Taste, Feel Good" dapat dilihat pada gambar 4 dibawah ini

\section{Sariné}
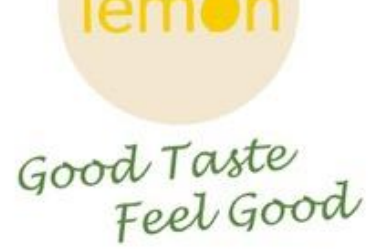

Gambar 4. Logo dan Tagline Sari Ne Lemon 


\section{Desain Kemasan Produk Baru Sari Ne}

Implementasi hasil desain logo dan Tagline dari produk baru UKM Sari ne Lemon yaitu Sparkling Lemon dengan ditempatkan pada kemasan cup plastic ukuran $400 \mathrm{ml}$ dapat dilihat pada gambar 5 .

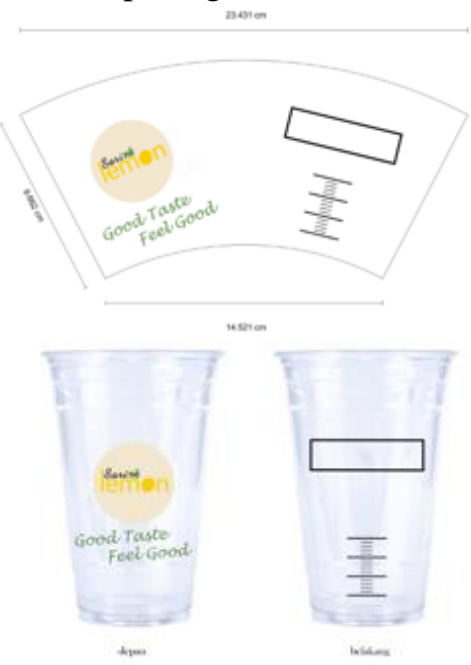

Gambar 5. Desain Implementasi Logo Pada Cup) $400 \mathrm{ml}$

\section{FGD Diskusi hasil desain Kemasan Sparkling Lemon Sari Ne Lemon}

Setelah desain logo dan tagline serta implementasi hasil desain logo dan tagline pada cup plastik $400 \mathrm{ml}$ sudah disiapkan selanjutnya adalah melakukan diskusi FGD hasil desain tersebut. Berdasarkan jadwal acara yang telah dibuat maka pelaksanaan kegiatan FGD kurang lebih bisa terlihat pada Tabel 1.

Adapun susunan acara kegiatan FGD pengabdian masyarakat yang dilaksanakan bersama UKM Sari Ne Lemon dapat dilihat pada Tabel 1.

Tabel 1. Susunan Acara FGD

\begin{tabular}{|c|l|l|}
\hline No & \multicolumn{1}{|c|}{ Acara } & \multicolumn{1}{c|}{ Durasi } \\
\hline 1 & Pembukaan & 5 Menit \\
\hline 2 & Penyampaian Hasil Desain Kemasan & 10 Menit \\
\hline 3 & Diskusi desain dan revisi Desain kemasan & 90 Menit \\
\hline 4 & Penutup & 5 Menit \\
\hline
\end{tabular}

Berikut ini adalah hasil pelaksanaan FGD kegiatan berdasarkan susunan acara yang telah dibuat.

1. Penempatan Logo dan Tagline lebih dibuat proporsional.

2. Kegiatan Focus Group Discussion dilakukan dengan owner dari Sari Ne Lemon.

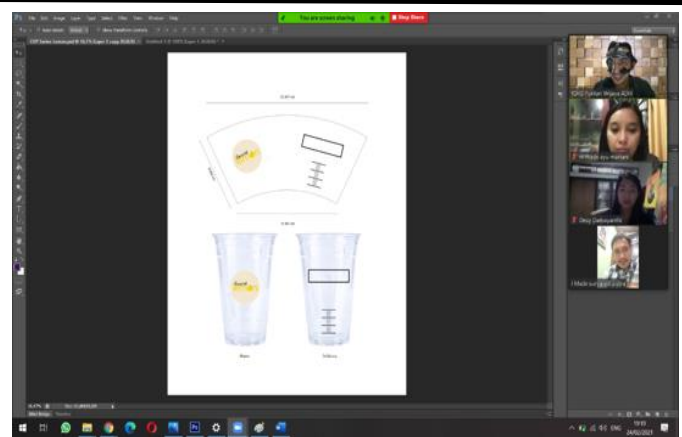

Gambar 6. FGD Bersama Mitra Sari Ne Lemon

\section{Pemberian bantuan Desain kemasan produk dan label dan pelatihan mengemas produk}

Pada tahap ini tim pengabdian masyarakat ITB Stikom Bali memberikan label Sari Ne Lemon yang telah didesain dan dicetak sebanyak 200 buah beserta gelas cup plastik sebanyak 200 buah kepada mitra. Dalam tahap ini, tim pengabdian masyarakat mengajak mitra untuk berlatih dalam pemasangan label Sari Ne Lemon yang baru pada gelas cup plastik.

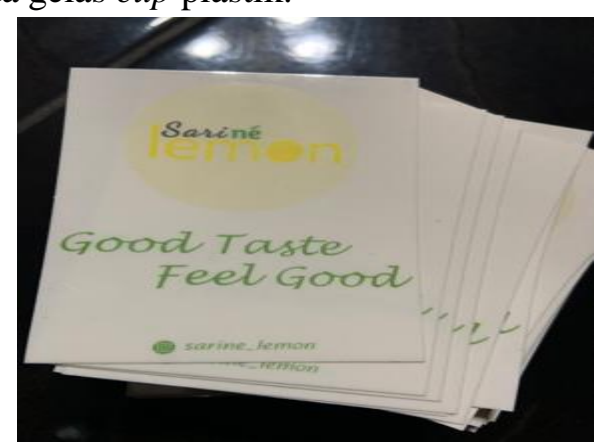

Gambar 7. Label Baru Sari Ne Lemon

Pelatihan pemasangan label baru digunakan dengan mendatangi dan melatih mitra secara langsung dengan menerapkan protokol kesehatan.

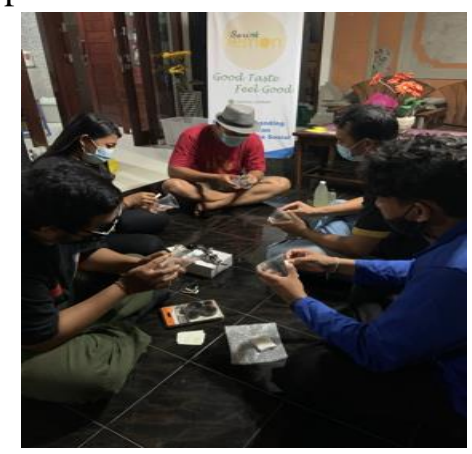

Gambar 8. Pelatihan Pemasangan Label pada Gelas Cup Plastik 
Luaran dari kegiatan implementasi branding produk Sari Ne Lemon yaitu sudah berhasil menerapkan desain kemasan produk Hasil dari evaluasi dan monitoring kegiatan memperoleh respon positif dari pemilik. Menurut pemilik masalah penerapan branding serta implementasi kemasan menjadi daya tarik produk. Dampak yang dirasakan oleh pemilik adalah jumlah penjualan meningkat sebesar $15 \%$ dari bulan sebelumnya .

Sedangkan masukan dari peserta kegiatan didapatkan mereka puas dengan pelatihannya, serta sangat antusias karena instrukturnya sangat semangat dalam menjelaskan materi pelatihan. Secara umum hasil dari monitoring dan evaluasi kegiatan mereka menyatakan kegiatan berlangsung dengan baik dan lancar.

\section{KESIMPULAN}

UKM Sari $\mathrm{Ne}$ lemon telah terbantu dengan berhasilnya mengembangkan kemasan produk baru mereka melalui desain kemasan dan implementasinya pada kemasan gelas cup ukuran $400 \mathrm{ml}$ Untuk menjaga eksistensi dalam pangsa pasar dan meningkatkan permintaan para konsumen, mitra diharapkan menjaga kualitas dari produk Sari Ne Lemon dengan baik. Tidak hanya itu, mitra juga diharapkan selalu gencar dalam melakukan promosi di media sosial. Pengembangan branding ini telah membantu mengatasi permasalahan mitra terutama untuk menarik minat konsumen dalam membeli produk dari Sari Ne lemon.

\section{UCAPAN TERIMA KASIH}

Puji syukur penulis panjatkan ke hadapan Tuhan Yang Maha Esa atas karunia-Nya, sehingga penulis dapat menyelesaikan Pengabdian Masyarakat yang berjudul "Pengabdian Masyarakat Pada UKM Sari Ne Lemon". Dalam penyusunan laporan ini, penulis banyak memperoleh petunjuk dan bimbingan dari berbagai pihak. Sehubungan dengan hal tersebut pada kesempatan ini penulis menyampaikan ucapan terima kasih kepada:

1. Bapak Dr. Dadang Hermawan., selaku Ketua ITB STIKOM Bali.

2. Rekan-rekan pada bagian Dir. PPM\&P.
3. Rekan-rekan Mahasiswa yang membantu pada saat pelaksanaan.

Penulis menyadari masih terdapat kekurangan dalam pelaksanaan pengabdian ini. Saran-saran yang membangun sangat diharapkan untuk menyempurnakan penelitian ini. Akhir kata penulis mengharapkan semoga pengabdian ini dapat memberikan kontribusi dalam pengembangan ilmu pengetahuan yang bermanfaat bagi kita semua..

\section{DAFTAR PUSTAKA}

Apriyanti, M. E. (2018) 'Pentingnya Kemasan terhadap Penjualan Produk Perusahaan', sosio e-kons, 10(1), pp. 20 27.

Kesumadewi, A. A. I. et al. (2020) 'Identifikasi Potensi dan Pengembangan Sistem Pertanian Organik menuju Bali Pulau Organik', Jurnal Bali Membangun Bali, 1(3), pp. 221-252.

Purnaningrum, E. (2018) 'Pengembangan Pemasaran Online dan Pengemasan Produk Berperan Terhadap Hasil Daya Jual', Jurnal Penamas Adi Buana, 2(1), pp. 7-10.

Trisnawati, I. (2018) Tingkat Kekeruhan, Kadar Vitamin C dan Aktivitas Antioksidan Infused Water Lemon Dengan Variasi Suhu dan Lama Perendaman. Universitas Muhammadiyah Semarang.

Wijaya, P. et al. (2020) 'Pengelolaan Pemasaran Online Produk Pertanian Desa Pelaga', WIDYABHAKTI Jurnal Ilmiah Populer, 3(1), pp. 81-86.

Yuendini, E. P. et al. (2019) 'Analisis Potensi Ekonomi Sektor Pertanian dan Sektor Pariwisata di Provinsi Bali Menggunakan Teknik Analisis Regional', Jurnal Geografi, 16(2), pp. 128-136. 